Journal of Qualitative Criminal Justice \& Criminology • 2021 | Volume 10, Issue 3

\title{
"Can you make it out \\ alive?"' Investigating Penal \\ Imaginaries at Forts, \\ Sanitaria, Asylums, and \\ Segregated Schools
}

Linda MusselI ${ }^{1}$, Kevin Walby ${ }^{2}$, Justin Piché ${ }^{3}$

${ }^{1}$ Queen's University, ${ }^{2}$ University of Winnipeg, ${ }^{3}$ University of Ottawa

License: Creative Commons Attribution 4.0 International License (CC-BY 4.0). 


\section{ABSTRACT}

We draw from literature on penal imaginaries to examine representations at fright nights and other staged cultural scenes from across Canada and the United States that reproduce justifications for imprisonment and punishment. Based on an analysis of online content and news coverage of fright nights organized at forts, sanitoria, psychiatric institutions/asylums, and segregated schools, we demonstrate that these displays mobilize stereotypes and shame to denigrate prisoners and naturalize imprisonment. Moreover, we show that these displays invoke health tropes concerning contagion to intensify fears regarding prisoners by portraying them as a threat to the social body, further rationalizing the existence of human caging as a means of addressing social unease and anxieties. Relying on ideas of risk and contamination, this penal imaginary reproduces punitive ideas that normalize the deprivation of liberty including in (COVID-19) pandemic times. We conclude by discussing the significance of our findings for the study of penal imaginaries and penal spectatorship.

\section{Introduction}

There is something about imprisonment that people find alluring the world over (Welch, 2015). This curiosity pertains to tours of decommissioned prisons and jails, as well as their representations on screen and other cultural sites (Brown, 2009). The process of representing punishment for profit in ways that are often demeaning to prisoners is common at prison museums (Walby \& Piché, 2015). Infatuation with penality extends to fright nights held at forts, jail and bail fundraisers held by nonprofit organizations, and other kinds of Halloween seasonal events meant to entertain and enthral. We define fright nights as seasonal horror themed events staged at night, while a jail and bail is an event where volunteers are "jailed" and supporters make donations for their "bail." Such events continue and take on new meaning during the COVID-19 pandemic era, with continued alarm over containing "risk," which we address in the conclusion of the paper.

Tourism and heritage managers are often concerned with the views of visitors (Devine, 2016), and may take steps to appease them, including by adjusting content or marketing them to be more entertaining, but not necessarily more educational. Museums and tourist sites often put artifacts on display, which draws the tourist gaze toward them, while stripping the objects of context (Ott et al., 2011). Digital displays and communications are a part of the new world of tourism and museums (Webmoor, 2008). Beyond professional curation, there are many amateur displays organized by a 
variety of agencies and actors (e.g., police departments and drug free coalitions as in Centreville's 'Haunted Trap House') that deserve inquiry using the tools from cultural studies, tourism studies, as well as critical criminology (Brown \& Carrabine, 2019; Edensor, 2001; Hall, 1997). While there is now a developed literature on penal tourism sites such as those situated in decommissioned prisons and jails across the world (Wilson et al., 2017; Huang \& Lee, 2020), less research has been conducted on amateur forms of penal heritage that are staged for entertainment and charitable fundraising.

Our purpose in this paper is to explore trends in penal tourism and spectatorship that have been overlooked in previous research on prison tourism. These amateur displays are meant to be variously entertaining or raise funds for community enterprises. To interpret these displays, we draw from literature on penal imaginaries (Carlen, 2008), which examines how ideologies that support punishment and imprisonment are created and reproduced in organizational settings. "Penal imaginaries" are the substantive and symbolic elements of penal operations that officials and other actors construct to shape how penal operations are interpreted.

Examining online content and news coverage from sites across Canada and the United States, we seek to answer the following question: what do the meanings of penality communicated in repurposed sites where people were confined under justification of illness, disease, and/or "deviance" reveal about penal imaginaries (Carlen, 2008)? Focusing on four types of repurposed sites-forts, sanitoria, asylums, and segregated schools-we discover a number of patterns: (1) a missing acknowledgement of colonialism and racism; (2) othering, fearing, and justifying the imprisonment of those deemed sick or deviant; (3) concurrent ongoing epidemics warranting attention (e.g., the poorly treated epidemic of drug overdoses); and (4) deficits in the public/government's sense of deservingness (e.g., who does versus who does not deserve to be treated and remembered with respect). The repurposed sites tend to denigrate prisoners in ways that legitimate carceral control. By revealing penal imaginaries through an analysis of activities in the decommissioned carceral sites noted above, we aim to uncover the "almost hidden structures of cultural and penal governance" (Carlen, 2008, xv).

We begin by reviewing literature on spectatorship and imaginaries in penal tourism. Second, we provide a note on our research design. Third, we provide our analysis of representations and displays at these cultural sites. Analyzing online content and news coverage, we demonstrate that these displays mobilize stereotypes and shame to 
denigrate prisoners and naturalize imprisonment. Moreover, we show that these displays invoke health tropes concerning contagion to intensify fears regarding prisoners by portraying them as a health threat to the social body, further rationalizing the existence of human caging as a means of addressing social unease and anxieties. Relying on ideas of risk and contamination, this penal imaginary is meant to be entertaining to raise funds for community enterprises, but ends up reproducing punitive ideas that normalize human caging. These insights are relevant during the COVID-19 pandemic when BIPOC communities are put at a heightened risk of contracting the disease due to barriers to care and risk factors related to poverty while also being subject to policing and a lack of harm reduction. Through the politics of deservingness, perceptions of worthiness as it relates to care or support (WatkinsHayes \& Kovalsky, 2016) further entrench existing patterns of marginalization. We conclude by discussing the significance of our findings for the study of penal imaginaries and penal spectatorship.

\section{Literature and conceptual framework}

\section{Penal spectatorship}

Literature on penal tourism has focused on formal spaces such as museums, rather than the varied amateur sites we examine. Museums are a central site for penal spectatorship. Welch (2013) examines prison tourism in museums located in different parts of the world including in London, Sydney, Melbourne, and Buenos Aires. Viewers often experience the museum as a space of performance (Patraka, 2001) and the meanings of displays contained therein that address controversial histories are fluid. When museums engage in more schlock-oriented displays, the performance can become more perverse. At such sites people view imprisonment and punishment from a safe distance, a process Brown (2009) refers to as penal spectatorship. Penal spectatorship entails viewing imprisonment through movies, television, tourism, and other cultural mediums that push the penal spectator further away from the realities of imprisonment, while claiming to bringing them closer to what the deprivation of liberty is like.

Penal tourism depends on a tourist gaze that creates a social distance between the prisoner and the penal spectator (Brown, 2017). This means there is an ethics to viewing and seeing in tourism. Penal spectatorship relies on shaming, stigma and mockery to denigrate the imprisoned (Morris \& Arford, 2019). Media and popular culture accounts of "crime" and "criminal justice" have long drawn on metaphors and analogies pertaining to monstrosity (Higgins \& Swartz, 2018). Constructions of the 
Other in popular culture operate to make human caging appear to be natural and necessary (Calathes, 2017). Such representations may legitimate and justify punishment (Lucken, 2013). Denigrating and excluding those deemed different, social constructions of the Other can also impede organizing and progress towards dismantling and building abolitionist alternatives to carceral control, which seek to deconstruct carceral systems of oppression including colonialism and racism.

\section{Penal imaginaries}

Museums and other cultural sites communicate ideas regarding the penal system and its functions in the world. One way to assess and interpret these ideas or ideologies is using the concept of penal imaginaries. Despite being quasi-mythical, penal imaginaries contain ideas and expressions that operate to assemble penal common sense and legitimize carceral institutions (Corcoran, 2011). Carlen (2008) described the concept in a way focused on the conveyance and reproduction of a specific ideological form circulating among workers inside penal spaces. Carlen was concerned with the consciousness of penal system workers and how almost mythical ideas (e.g., the role of the prison in society to "rehabilitate") are learned, communicated, and adopted by prison staff such as guards. Carlen argues that these penal imaginaries, laden with tropes about the risks embodied by prisoners, become the basis for justifying continued imprisonment and punishment. She suggests the idea of penal imaginaries can be used to assess how these ideas are taken up in popular culture and by the general public in ways that reinforce penality. Focusing on penal imaginaries forces the penal tourism researcher to go beyond administrative issues in analyzing curation to assess the relations of carceral power and inequality that are reinforced through representations and other vessels of ideology.

Outside the prison, penal imaginaries are fictions of imprisonment communicated in popular culture. These forms of popular culture include amateur exhibitions like fright nights and escape rooms. For example, Armstrong (2018) argues the ideas of waiting and hiatus are tropes used in movies and television shows about prison, but that these ideas are over-emphasized. Prisons are also full of movement and activity. Communicating the opposite creates a fictive and misleading notion of confinement. Particular objects (e.g., metal bars) and spaces (e.g., cells) tend to define the image of penality in public culture. However, these may not be the same objects and spaces that define confinement for prisoners, revealing the discrepancy between penal imaginaries and the lived experience of the carceral that they depict. Carrabine (2016) shows how accounts of medieval punishment rely on a penal imaginary that is not accurate, but 
did much to dramatize scenes of torture, making it appear as everyday life. Penal imaginaries regarding more recent history during the $20^{\text {th }}$ century through visual, textual and audio materials can be equally inaccurate. Philosopher, activist, and former prisoner Angela Davis $(2005,35)$ defines prisons "not only as an apparatus to repress political activists, but also an institution deeply connected to the maintenance of racism," something which penal imaginaries distract penal spectators from.

The visual rhetoric in the penal imaginaries communicated in advertisements and posters often invoke stereotypes (Linnemann et al., 2013). These kinds of scenes of blood and pain misrepresent the complexity of issues of transgression, but also often fail to demonstrate any compassion or moderation. There is often little restraining a penal imaginary from being circulated in state discourse or in more entertainmentoriented popular culture. Such imaginaries include a rehabilitation fiction and supervision as diversion fiction. Indeed, the fictions "that sustain and legitimate penal institutions, policies, and practices" (McNeill, 2019, 298; also see Forsdick, 2019) are powerful forms of both official discourse and popular culture.

Penal imaginaries mobilized during fright nights in carceral spaces, along with other prison-themed fundraisers, rely on denigrating tropes about imprisoned people which have been mixed with stereotypes related to living with mental health and other medical issues. The tropes of risk, disease and contagion ((e.g., HIV, hepatitis B and C, tuberculosis; Kamarulzaman et al., 2016) and COVID-19 (Burki, 2020)) are often used to convey a sense of threat posed by a dangerous Other in state communications (Kuperavage, 2017; Abeysinghe \& White, 2010). Such tropes are also racialized and tethered to colonial understandings of human superiority and inferiority (Sargent \& Larchanche, 2014; Kinzelbach, 2006). Likewise, in escape rooms there is a tendency to uncritically tap into punitive and voyeuristic desires of those with privileged positions (Stuit, 2020). Activists and scholars have organized breaching experiments to challenge our normative societal order (Lafontaine et al., 2020), yet there is often a lack awareness of what it means to mimic and theatricize confinement. As we reveal, penal imaginaries regarding prisoners on display at makeshift and amateur exhibitions like fright nights rely on notions of contagion and contamination to dangerize carceral subjects and justify their containment.

\section{Note on method}

We collected online content describing tourism uses of repurposed sites of confinement from corporate and state-operated webpages, posters, event listings, and social media (Facebook and Twitter) posts produced by repurposed site operators. We 
also gathered and analysed a total of 88 stories on fright night or Halloween-themed events using Google news, Google searches, Facebook and Twitter. Results were limited to those published between 2010 and 2020. The search was focused on Canada and the United States. We located 17 distinct events in Canada, and 51 in the United States. Different sites of confinement emerged in the data such as forts, asylums, reformatories, schools, hospitals, police stations, sanitoria, and prisons. Other sites like cultural centres with events operated in partnership by police were also included. We opted to focus on sites of confinement less researched in the penal tourism and spectatorship literature including forts, sanatoria, asylums, and segregated schools for analysis. For this paper, we focus on one representative example of each type of site. Such sites were selected for the amount of rich detail available required for comparative analysis. Of the four sites examined, two sites are from Canada and two are from the United States. For the selected sites, we gathered a further 20 news stories and examined visitor reviews available from Trip Advisor, Facebook, and Twitter.

Analyzing the images and depictions contained in the material gathered entails focusing on the manifest and latent content contained in these representations (Wilson \& Landon-Hays, 2016). Coding was both inductive and deductive. Inductive themes (viewership, the role of "authenticity," fear of otherness) emerged from the data. Deductive themes include colonialism, othering and disability, racism, connection to pandemics, and deservingness. We used qualitative content analysis to examine communicative material as embedded in a context of communication, paying careful attention to authorship, audience, language, verbal and non-verbal material, and sources (Mayring, 2004). By organizing the text and imagery into categories, this approach allows the use of inductive and/or deductive themes to be analysed (Elo \& Kyngas, 2008). Penal spectatorship emerged as a key theme arising from the data, whereby prison-themed content was communicated as a central capital generating strategy used by repurposed site operators to spark consumption and enjoyment amongst visitors.

\section{Findings and analysis}

We focus on four locations of confinement that have been temporarily or permanently repurposed for entertainment, education, and tourism. The first type of site we investigate are forts, examining Lower Fort Garry in Manitoba, Canada, located on the traditional territory of the Anishinaabe, Cree, Oji-Cree, Dakota, and Dene peoples, as well as the homeland of the Métis Nation. This example illuminates the unacknowledged history and ongoing legacies of colonialism, which continues to be 
obscured not only at this site but others. There is a lack of acknowledgement of this history, while public site operators evoke themes of disease and invasion (e.g., escaped convicts in spaces they should not be) in entertainment activities.

The second type of site we examine are sanitoria, exploring Tranquille Sanitorium in Kamloops, British Columbia, which evokes continual othering of people living with infectious disease and mental health issues, and fosters a fear of both. This is of interest during the COVID-19 pandemic (as we discuss in the conclusion) where fear of disease and treatment of people exposed to the virus comes hand-in-hand with punitive isolation tactics.

Third, we examine asylums, which similar to sanitoria, engage in continual othering, playing into a fear of people living with mental health issues and disabilities. We explore how meanings of physical and mental health intertwine at the Pennhurst asylum in Spring City, Pennsylvania.

Lastly, we examine the Centreville, Maryland "Trap House," which is a former segregated school turned cultural centre where police participate in Halloween events evoking confinement. This example provides lessons on meanings that sustain the concurrent epidemics of overdose deaths and policing violence. Through an examination of these four different cultural sites we reveal the salience of penal imaginaries invoked in past sites of confinement and their role in legitimating the deployment of carceral power in the present.

\section{Forts}

Forts were built for military and trading (Voorhis, 1930), and have been used in advancing national mythologies about identity, citizenship, and Indigenous peoples (Donald, 2009). An example in Canada with a prison escape theme is Fort Henry (Kingston, Ontario), while examples in the United States include paranormal tours at Fort Delaware (Delaware) and haunted tours at Fort Leavenworth (Kansas). The prison break themed event at Lower Fort Garry, "Fright at the Fort: Prison Break," was held in 2015. The haunted tours continue each year, a place where tuberculosis patients were confined and prisoners jailed. Lower Fort Garry was built in 1830 and is located near Winnipeg, the site of the Red River Rebellion (1869-70), an uprising by Métis led by Louis Riel, against the transfer of the territory of Rupert's Land to the Dominion of Canada (Andersen, 2014). Treaty 1 was negotiated and entered into in August 1871 at Lower Fort Garry. It is considered controversial due to the differing understandings of 
the treaty and what agreements entailed. The fort is a National Historic Site near Winnipeg, which is described by Parks Canada (2019) as:

mark[ing] a turning point in Canada's history with the making of Treaty No. 1 , the first of the numbered treaties. The Fort was home to the Hudson's Bay Company and a hub for the First Nations trappers and Hudson's Bay Company traders who helped build modern western Canada.

This is a glowing account of history for a space associated with death and suffering. The fort has been groomed into a "marquee" heritage tourist attraction where accounts of history are generic, exaggerated and misleading (Coutts, 2016). At this site, Indigenous history is "essentially grafted onto site interpretation and site spectacle" (Coutts, 2016, p. 12). The ongoing colonial violence of erasure tied to the state-run fort is not fully discussed in portrayals of the site, nor in the haunted tours. Instead, the penal imaginaries constructed as official discourse (McNeill, 2019) mobilize tropes of contagion and risk to convey a threat of the Other seated in colonial understandings (Sargent \& Larchanche, 2014; Kinzelback, 2006).

\section{Image 1.}




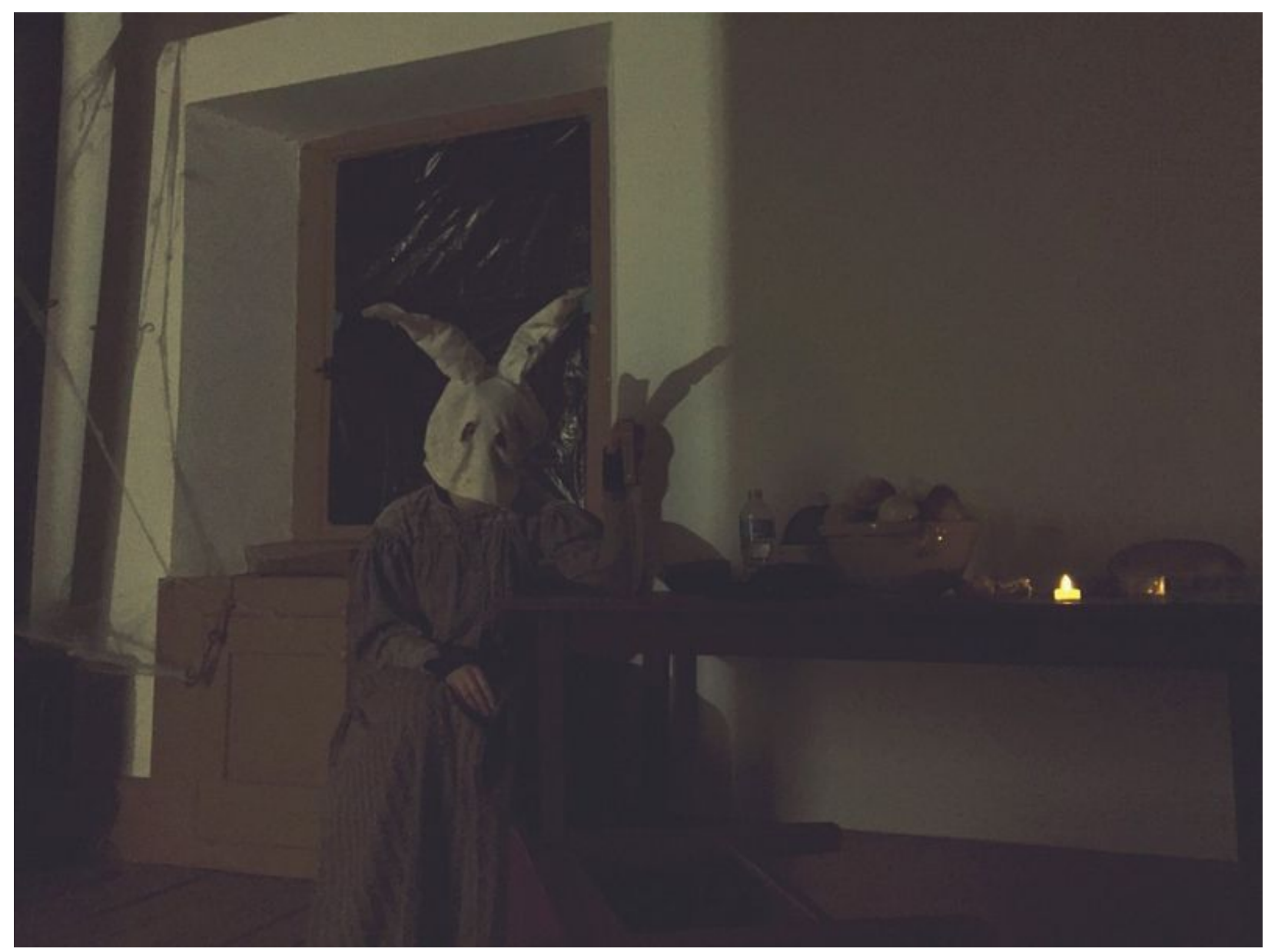

Description: "In another dimly lit room, just beyond a doorframe, a young actor sits motionless in a burlap bunny mask, its eye-holes drooping and hollow. Her hand is clutched tightly around a six-inch blade dug into the table" (Rousseau, 2015).

Coverage of the prison break-themed tour focuses on the interpretation of the events by staff and spectators. Staff note as a point of prurient interest that Lower Fort Garry "was where the first penitentiary and mental health asylum in Manitoba were" (Rousseau, 2015), but do not explain the colonial significance of this site such as the Red River Rebellion. Instead, this violence is construed as a voyeuristic opportunity for fright entertainment, viewing suffering caused by colonialism as relegated to the past. Regarding tuberculosis, a devastating bacterial infection where those infected where confined to the fort, a tour guide shares, "Tuberculosis was a horrible problem, too, ... they kept children dying of the disease inside a small shack" (Rousseau, 2015). The spectator views the site as a place of safe, historical fright entertainment, "Despite many screams, jumps and near pant-wetting moments throughout the rest of the tour, the small cabin was perhaps the scariest spot. It's the history of the haunt that made it truly creepy" (Rousseau, 2015). 
This account also lacks attention to the ongoing social issues faced today. People still suffer from tuberculosis. Indigenous people are put at a higher risk (Gallant et al., 2017), especially those subjected to substandard housing and healthcare (Patterson et al., 2018; Patel et al., 2017). Indigenous people made up approximately five percent of the total Canadian population in 2015 , but accounted for 17 percent $(281 / 1,639)$ of all reported tuberculosis cases (Gallant et al., 2017). Similarly, staff share that they have heard of historical instances of "people painfully freezing to death in the winter along the banks of the river, and that someone in the town was allegedly a violent serial scalper" (Rousseau, 2015), yet do not situate these instances of violence in relation to ongoing colonialism. Indigenous people still freeze to death in the prairies when sent on "starlight tours" by police (Razack, 2015, 2014), and there are thousands of Missing and Murdered Indigenous Women and Girls (MMIWG) (National Inquiry, 2019). "Starlight tours" refer to police picking up Indigenous people and driving them outside city limits. In the winter this can prove lethal (Razack, 2015, p. 173). Such omissions at the site create social distance between the confined and the penal spectator (Brown, 2017), and operate to make imprisonment appear natural and necessary (Calathes, 2017) to keep those who purportedly represent "risk" isolated far away.

An important layer of the prison-break haunted tours at Lower Fort Garry is the exploitation of fear vis-à-vis the "ill" or "deviant" people escaping confinement and the heroism of police in creating order. At the entrance of one house, named "Trial and Horror," "a woman in a rocking chair yelled something akin to 'they'll get you!' and 'they say I'm crazy?'” - the implication being that prisoners on the loose are insane and dangerous. In event marketing from the provincial and regional tourism bodies, the tours described "Lower Fort Garry penitentiary" as having "been overrun and the most heinous inmates are on the loose" (Travel Manitoba, 2015; Tourism Winnipeg, 2015). Visitors also "encounter locals and North West Mounted Police officers as they try to keep order and try to end the bloody rampage of escaped convicts" and warned to "Watch your back, because you could be the next victim" (Travel Manitoba, 2015; Tourism Winnipeg, 2015). Framing police as protectors ignores the violence they engaged in historically and perpetrate today (Palmater, 2016), along with the displacement Indigenous people experienced during white settlement (Daschuk, 2013; Taiaike et al., 2005). Local vigilante residents of the fort (i.e., white settlers) are also portrayed as protectors, while spectators are portrayed as brave and deserving of protection.

Reviews of the fort are positive. For one spectator, it was "great for a Halloween visit," they were "pleased with the tour," thought "the history of the fort is amazing," and 
"can't wait to visit [again]" (Trip Advisor, 2011). Bombarded by benevolent myths of nationhood, the fact that Indigenous voices were missing went unnoticed by visitors who commented on the site. Indigenous leaders such as the late Arthur Solomon have spoken about the way carceral institutions are naturalized and portrayed as necessary. Kesheyanakwan (Fast Moving Cloud) Solomon was an Ojibwe Elder, residential school survivor and spiritual leader. He helped win the right to allow Indigenous healing methods and traditional ceremonies in prisons. Such representations ignore, in his words, that "We have lived here since long before there was written history. And we had no prisons, we had no police, we had no prison guards. We had no lawyers and no judges, but that does not mean that we had no laws to live by" (Solomon, 1990, p. 2).

\section{Sanitoria}

Sanatoria were medical facilities for long-term illness, most typically associated with the treatment of tuberculosis, before the widespread use of antibiotics (Burke, 2018). Some repurposed sanitorium examples include Idaho State Tuberculosis Hospital (Gooding, Idaho) and Waverly Hills Sanatorium (Louisville, Kentucky), both are used for ghost tours. Escape rooms are held at Tranquille Sanatorium in Kamloops, British Columbia annually with different themes. Tranquille Sanitorium's "Escape from Padova" (2018) was an escape room/tunnel with a haunted asylum theme. Escape rooms are games where a team of players find clues, solve puzzles, and accomplish tasks in locked spaces to accomplish a specific goal (e.g., escape) in a set amount of time. According to the Kamloops Museum and Archives (Gilbert \& Fedorak, 2018), the sanatorium was built in 1907 to treat patients with tuberculosis and did so until 1958. The facility did not treat or employ Indigenous or Asian peoples until after World War II (Norton \& Miller, 2002). Prior to this, Indigenous people were sent to segregated hospitals as part of colonial assimilation efforts in Canada (Drees, 2013; Lux, 2010, 2016). Residential schools and sanatoria were interconnected institutions within the same system of management (Kormarkisky et al., 2015), both reinforcing racial distinctions and inequalities (Lux, 2016). As Kormarnisky and colleagues (2015) find through interviews with Indigenous people who experienced tuberculosis, "What happened 'years ago' profoundly affects the health and well-being of people diagnosed with TB today." Following 1958, the sanatorium facilities were transferred to the Mental Health Services Branch of the provincial government and the site was used as an institution for people, ranging from children to seniors, living with intellectual disabilities. At its peak, Tranquille housed 700 people, a quarter of the provincial population of institutionalized people living with intellectual disabilities (Purvey, 2018). In 2003, following the testimony from survivors of Woodlands institution the British 
Columbia government issued a formal apology to former residents who suffered abuse at now-closed provincial institutions that imprisoned people living with intellectual disabilities (Globe and Mail, 2003). Purvey (2018) states there are no accounts of abuse at Tranquille featuring the voices of those who were confined there, even in the oral history project conducted by Block (2018).

In 2018, the provincial government extended compensation to survivors of abuse at the Woodlands site (Canadian Press, 2018). Woodlands is another institution that confined people with cognitive disabilities in British Columbia. Upon receiving compensation for the abuse he endured, Woodlands survivor Bill McArthur encourages "other survivors to reach out to the provincial government to receive their redress as well" and added that "This vindication, I hope, will allow them to live the rest of their lives with a sense of self respect and dignity" (Canadian Press, 2018). Luanne Bradshaw, also a Woodlands survivor, said, "I'm very proud of how far I've come in just being a free person, living life as I see fit and making sure that my identity doesn't get forgotten" (Shaw, 2018). Survivor testimony, along with their aspirations for recognition and respect, are missing at Tranquille.

The site owners, Farm Fresh/Tranquille Ltd. Partnership, exploit fear of people living with diseases and mental health issues, while claiming to provide accurate accounts of the site's history. Coverage notes that, "Every year, this historic property looks for ways to be creative in telling the story of Tranquille." Yet this story telling does not incorporate accounts or the participation of those who were confined there. This absence creates a distance between the confined and the spectator (Brown 2017). The delivery of this information begins with "the first tunnel escape room with actors" (Trudeau, 2018) who rely on dramatization, stereotypes, and tropes. Being confined in the space where others were once confined is framed as entertainment through a partnership with Chimera Theatre. The event relies on representations of risk, illness (Abeysinghe \& White, 2010), and theatrics for entertainment. Those who are sick or those who are differently abled are threatening because they are Other. The website reads, "You've snuck into Padova, now you have to find a way to get out. Can you make it out alive?" and "You're trapped underground ... and you're not the only one."

The site co-owner, Annette Mcleod, claims, "We tell true events that have happened through interactive tunnel theatre. You interact and move through the tunnels with the actors into different rooms" (Trudeau, 2018). Co-owner Tim Mcleod also notes, "The whole idea is to freak people out" (Potestio, 2018). The emphasis of the event is to attract millennials (thus the name choice of Padova, which younger people use for the 
site), with the long-term goal of generating interest and encouraging housing development on the picturesque piece of land (Potestio, 2018). This lays bare the connection between penal imaginaries, liberalism, and capitalism (De Giorgi, 2010). Tranquille Ltd. Partnership, for which McLeod is the development manager, are continuing to look for partners to invest in the property, privileging the attraction of attention and capital accumulation over providing an accurate and comprehensive history of the site (Potestio, 2018). The escape room does attract interest, while the penal imaginaries communicated naturalize rather than trouble confinement, and do not reflect the stories or wishes of the people who were confined there. A student notes the escape room is frightening, with no mention of the people once confined there:

Raggy halls, leaking ceiling with missing tiles and graffiti-stained walls grace you once inside the former asylum. The setting was truly creepy, with the damp air, the missing floor tiles and the signs of old equipment still being stuck to the walls giving a truly haunting experience (Hunter, 2018).

\section{Image 2.}




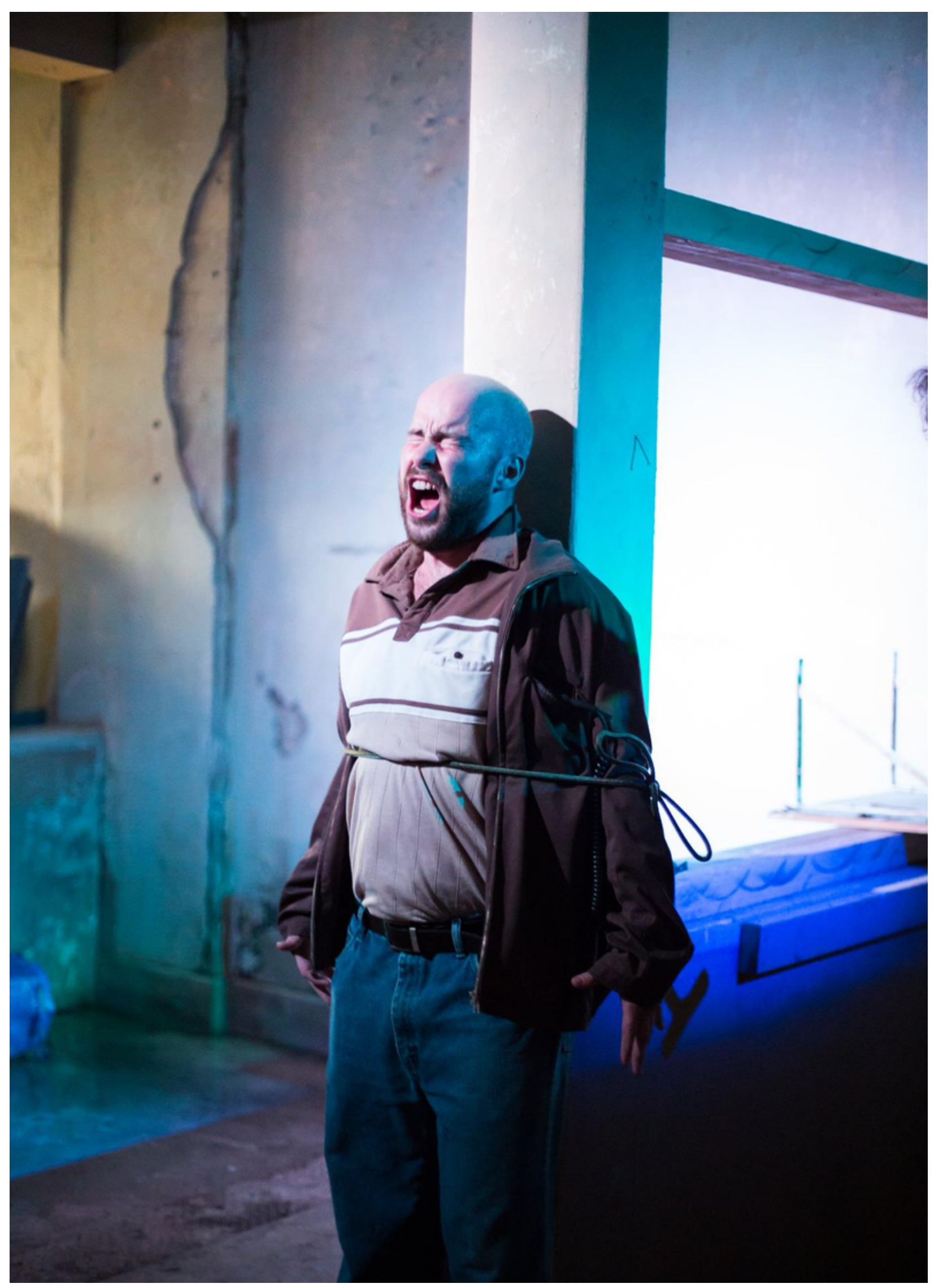


Others also praise the escape room, wanting to return for additional frights: "It was cool to get into the tunnels and check out this old spooky place and the actors were really good. We also did the escape room and it was also awesome" and "They need more (and better) actors ... more people jumping out at you, banging on walls, screaming and scaring you. We should have been able to explore the property a little, even tour another building" (TripAdvisor, 2018). The escape room operates to make confinement appear natural by providing entertaining displays through theatre developed by those with no lived experience, while substantive information about confinement is lacking. There are no accounts that detail how people who were confined at Tranquille feel about its current use. There is no discussion of the institutionalization of people with disabilities or experiences of harm and abuse.

\section{Asylums}

Asylums are the precursor to modern psychiatric institutions and confined people deemed mentally ill, intellectually disabled, and physically disabled (Appleman, 2018). Some repurposed hospital/asylum sites in the United States include Bartonville Asylum (Illinois), Weston State Hospital (West Virginia), and Eloise Asylum (Michigan).

Repurposed psychiatric hospitals/asylums in Canada include Lakeshore Psychiatric Centre (Toronto, Ontario) and Notre-Dame de la Chesnaie house (Sainte-Clotilde-deHorton, Quebec). Located in Spring City, Pennsylvania, the Pennhurst State School and Asylum is a former institution repurposed as a hospital-themed haunted house attraction. From 1903 to 1979, Pennhurst, originally known as the Eastern Pennsylvania State Institution for the Feeble-Minded and Epileptic, confined people living with cognitive and physical disabilities in Southeastern Pennsylvania (Beitiks, 2014). In 1913, the legislature appointed a Commission for the Care of the FeebleMinded, which stated that people with disabilities were unfit for citizenship and posed a menace to the peace, requiring a program of custodial care (Downey, 2017). The Commission had a eugenic goal to prevent those confined from having children. Pennhurst's Chief Physician quoted Henry Goddard, a eugenicist, as follows: "Every feeble-minded person is a potential criminal" (Pennhurst Memorial \& Preservation Alliance, 2015). At its peak, the abusive institution confined 3,500 people (Downey \& Conroy, 2020).

This site differs from the others in this paper as it has attracted considerable condemnation of its operation, both prior to its closing and now during its repurposing. The catalyst in this criticism of Pennhurst came through the documentary by Bill Baldini (1968) entitled "Suffer the Little Children". Pennhurst is a site considered 
pivotal in understanding the disability civil rights movement (Downey \& Conroy, 2020), yet this information appears to be missing in the events now staged there and most often absent in related media reporting. In one outlier article, coverage notes that Baldini and sociologist Jim Conroy believe "the site should become a memorial to the past, not a haunted house" (Tarabay, 2010). Conroy was also given a platform to discuss the painful events that took place at the site:

I drove up in 1970 in my dad's blue Chevy, and I saw a place with 3,700 people in it that was built for far, far fewer. And I saw things that I will never forget. ... Think of a ward of infants and children from the ages of six months to 5 years old. ... There are 80 of them in ... metal cages (Tarabay, 2010).

\section{Image 3.}

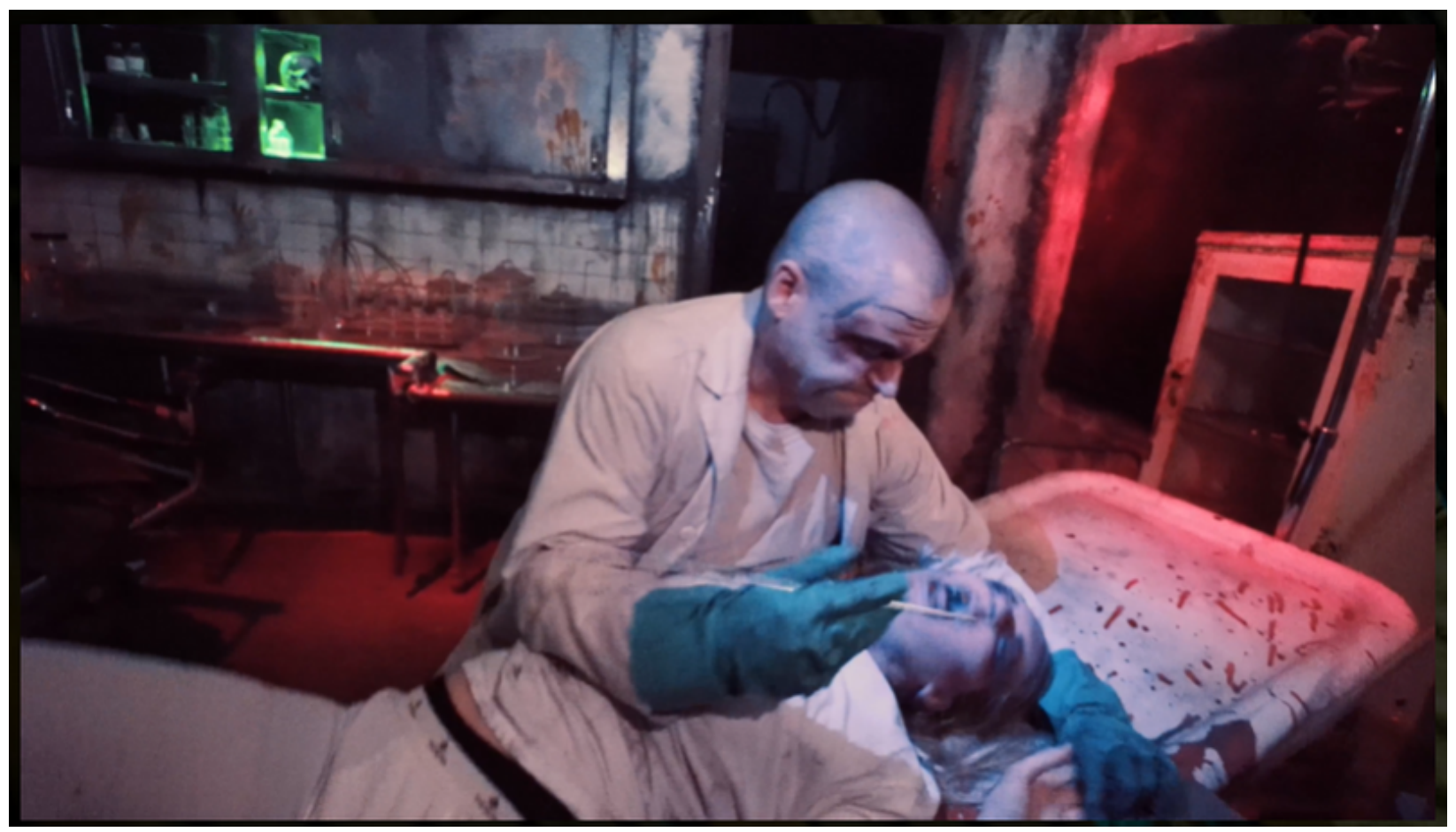

Still from video. Description: "Pennhurst Asylum is home to some of the world's most dangerous criminally insane ... Guests will visit the cells of our most hostile patients and must navigate Maximum Security" (Pennhurst Asylum, n.d.a).

The thousands who visit the site and those profiting from it outnumber these critical voices. Former owner Richard Chakejian claims, "We went well out of our way to make sure that this event doesn't mock or mimic any of the handicapped. And I believe that the public that comes through here know the distinction and the difference between 
making fun of something and a Halloween event" (Tarabay, 2010). Chakejian also noted that at least 17,000 people have come since the haunted house opened for the Halloween season in 2010, "contributing to the local economy" (Tarabay, 2010). Others (e.g., Betik, 2014) have remarked that the depictions of confinement are inappropriate and the profits generated do not justify them. The site website uses metaphors and stereotypes to peak the interest of potential visitors (Linnemann et al., 2013) such as "Pennhurst, the legendary haunted hospital complex has opened its doors after being abandoned for 25 years! Pennhurst haunted asylum is Pennsylvania's Scariest destination haunted house! The fear is real at Pennhurst!" (n.d.b). Accounts from TripAdvisor illustrate the nature of fright entertainment at the site, which both "evokes and erases" Pennhurst's past (Beitik, 2014), with a focus on a doctor and incarcerated patients, meant to ironically distance the asylum from its history.

Tripadvisor (2017) reviews note "What sets this apart from other attractions is the location. Taking place on the eerie grounds of Pennhurst definitely helps set the mood." That it was a site of confinement makes it more entertaining for tourists because "When you hear the stories of what went on there, it only adds to the scare" (Tripadvisor, 2020). Rare accounts also note that education takes a back seat to entertainment, including one that noted, "The attractions are good, but it is sad to see that the history of Pennhurst that was displayed in the first room the first year has been no longer for the last couple of years" (Tripadvisor, 2016). When there was a museum exhibit, spectators were moved through it quickly (Beitik, 2014). As reported in 2014, the admission line movie screen displayed scenes from Suffer the Little Children spliced with footage of lobotomies (Beitik, 2014). Real artifacts from Pennhurst, including an electro-shock therapy machine, are used as props. Former staff led a small number of tours, but persons who were confined there are not given a platform.

Despite a few criticisms, spectator accounts mostly focus on the entertainment provided by actors who portray prisoners confined at the site as monstrous (Higgins \& Swartz, 2018). In the words of one spectator, the monstrous depictions of the confined is "my favorite part of all the attractions" such as "the girl (nurse) who's face was covered in blood and she was crept up over top of a hospital bed eating a body ... it was super disgusting looking, obviously, but, this girl was made for Halloween, she looked like she was actually eating a corpse, it was just so realistic" (Tripadvisor, 2019). Visitors also reported being immersed in dramatized experiences of confinement: "I've been grabbed, touched, had my head measured with sharp objects cause they want my brain to give to the crazed doctor" (Tripadvisor, 2019); “[They] 
even gave you sugar pills to swallow-we loved it!” (Tripadvisor, 2019); “[I’ve been] even picked up by one of the characters and thrown into a steel cage and asked, what do I think of his cell?" (Tripadvisor, 2018); "the actors (and there are hundreds of them) actually crawl on the ground and floors and grab your ankles, feet, pull your hair" (Tripadvisor, 2017). Participants often claim it is enjoyable, with one review noting, "Despite some people claiming that it disrespects the past history of the place, it really just comes down to having some good scary fun during the Halloween season" (Tripadvisor, 2017).

These accounts differ significantly from those with lived experience. The late Roland Johnson (1994, p. 237), survivor of Pennhurst and president of Speaking for Ourselves, said, "people could not think that handicapped people could do this [to create an advocacy organization]; that they need to be put away somewhere far away from us. That's where discrimination is coming." Remarking on the haunted tours, Jean Searle, co-president of Pennhurst Memorial and Preservation Alliance and former resident of another institution, notes: "I don't want to relive the hell that I went through. ... I want to try to forget" (Walters, 2010 cited in Beitiks, 2014). Liz Spikol (2017), a journalist with a bipolar diagnosis who took the haunted tour, wondered, "Is this how people see me? How is that possible? There is a whole Halloween industry built around the idea that 'crazy people' are terrifying”. Accounts that challenge the othering of people living with disabilities are missing in the haunted tours replete with scenes where spectators can regale in human suffering and confinement.

\section{Segregated schools}

Brown v. Board of Education of Topeka was a landmark 1954 US Supreme Court case in which the justices ruled unanimously that racial segregation of children in public schools was unconstitutional. Prior to Brown, racial school segregation was absolute in the South and widespread in many school districts in other parts of the country. Students remain de facto segregated across schools and districts today in the United States (Reardon \& Owens, 2014). Centreville, Maryland's "Haunted Trap House" is a haunted house attraction held in the Kennard African American Cultural Heritage Center (KAACHC) in partnership with the police and court system featuring content that mirrors substance use issues in the community (Dvorak, 2019). This event features updated content from the 1989 "Haunted Crack House" event held in the Centreville old jail (Dvorak, 2019). A "trap house" is an apartment or private house, sometimes in public housing projects, where multiple people who sell drugs do business (Haunted Crack House, 2019). The name was updated to reflect the language 
that youth use, as this project is targeted toward middle school age students (Jaime, 2019). The attraction takes spectators through scenes depicting a teen who becomes "entangled in the web of addiction." The haunted house focuses on a concurrent epidemic to COVID-19: opioid overdoses and deaths. Coverage explains overdose as a significant issue in Centreville, but does not use the language of epidemic despite the fact that “Queen Anne's County on Maryland's Eastern Shore has one of the nastiest rates of opioid overdoses and deaths in the nation ... it's soaring here" (Dvorak, 2019). According to the Maryland Opioid Operational Command Centre (2020), there were 561 opioid-related deaths in the first quarter of 2020 and fentanyl was involved in the majority (93.2 percent) of overdose fatalities. Wanting to do something about overdose deaths, the town decided to make a haunted house out of the site.

The event location in the KAACHC is used without context or discussion of the schoolto-prison pipeline targeting Black people in the United States. The Centre is in a former Black segregated high school, which opened in 1936 (KAACHC, 2018). Education was not racially integrated in the county until 1967 (KAACHC, 2018). The site was vacant for 40 years until purchased by the Kennard Alumni Association and transitioned to a community centre that models Black history (KAACHC, 2018). Haunted tour images show white event participants and speakers. There is no discussion of how criminalization and overdoses overwhelming impact racialized people in Maryland at a time when Black communities are experiencing dramatic increases in overdose deaths, along with widespread imprisonment of drug users and disruption of their families. The rate of increase of drug overdose deaths amongst Black people between 2015-2016 was 40 percent (SAMHSA, 2020). The Anti-Drug Abuse Act of 1986 resulted in mandatory and severe sentencing for low-level, nonviolent drug offenses, confining Black people in mass numbers (Nunn, 2002). In 2017, Black people made up a third of the sentenced prison population, despite only representing 12 percent of the population (Pew, 2019). In 2012, Black people accounted for 39 percent of the population confined for drug-related offenses (Taxy et al., 2012). Black people are doubly stigmatized by race and substance use; stigma contributes to discrimination and harsh punishment instead of treatment and recovery services (Kulesza et al., 2016) or access to harm reduction. Black children continue to be inducted into a school-to-prison pipeline that begins with segregated schools, detentions, and disproportionate placement in special education (Sealey-Ruiz, 2011).

Sponsored by the Queen Anne's County Drug Free Coalition, the "Haunted Trap House" event is presented in partnership with the county Departments of Health and Emergency Services. Creating experiences that naturalize imprisonment, the tour 
features "real police officers who stage arrests, a real judge to hand down a sentence. They even have real prisoners, who are encouraged to interact with the visitors" (Dvorak, 2019). The prisoners brought in are nameless in media coverage and treated as an attraction, allowing participants to "meet a real-life opioid-addicted prisoner brought from the Queen Anne county jail” (Allen, 2019), whom organizers use for authenticity. In news coverage, an incarcerated person is pictured in prison clothing and behind bars at the event (Allen, 2019). The focus is not on the end result of criminalizing drug use and the mass imprisonment of Black people. Instead, the focus is on creating fright of substance use issues: "townspeople decided to capitalize on that fear this Halloween. They have created a huge haunted house. Only, rather than witches and mummies, it's a tableau of the nightmare the entire county is enduring-a journey through drug addiction" (Dvorak, 2019). The event also provides the opportunity for police to engage with children and youth, allowing a police-partnered public service announcement (PSA) against drug use:

The haunted house at the [KAACHC] will have scenes from a drug den, a frightening arrest, a court hearing, a jail cell, a wrenching family crisis, a harrowing overdose. They will go into the dark and dirty details of shooting heroin and fentanyl. It's a walking, shrieking, living, screaming PSA.

Images 4 and 5 below illustrate two of these scenes, an overdose featuring the participation of county police and a staged court hearing relying on tropes (e.g., "drug dealer boyfriend").

\section{Image 4.}




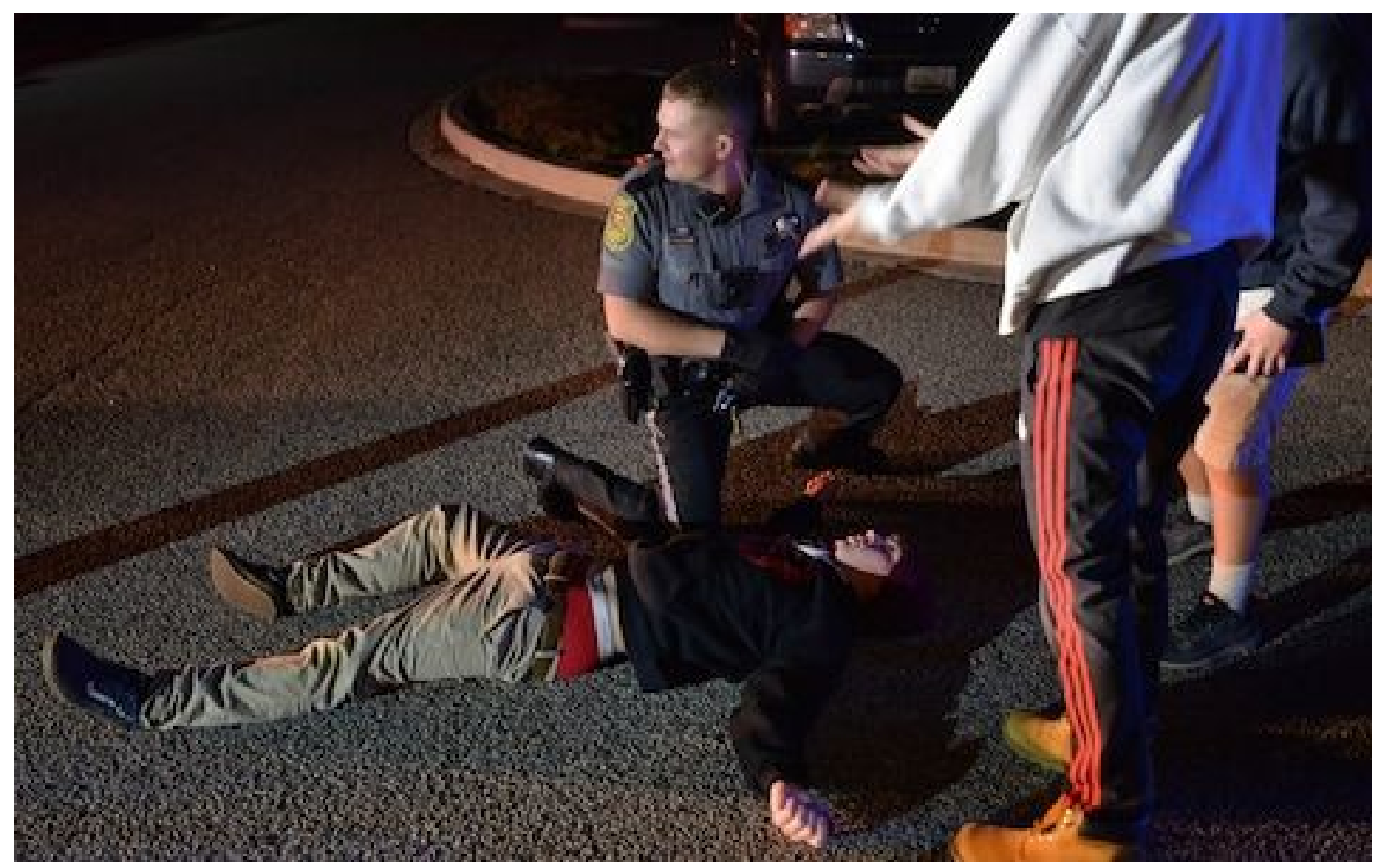

Description: "Student actors portray the drug overdose of a friend at a street party."

Image by Dermot Tatlow and caption by Allen (2019).

Image 5. 


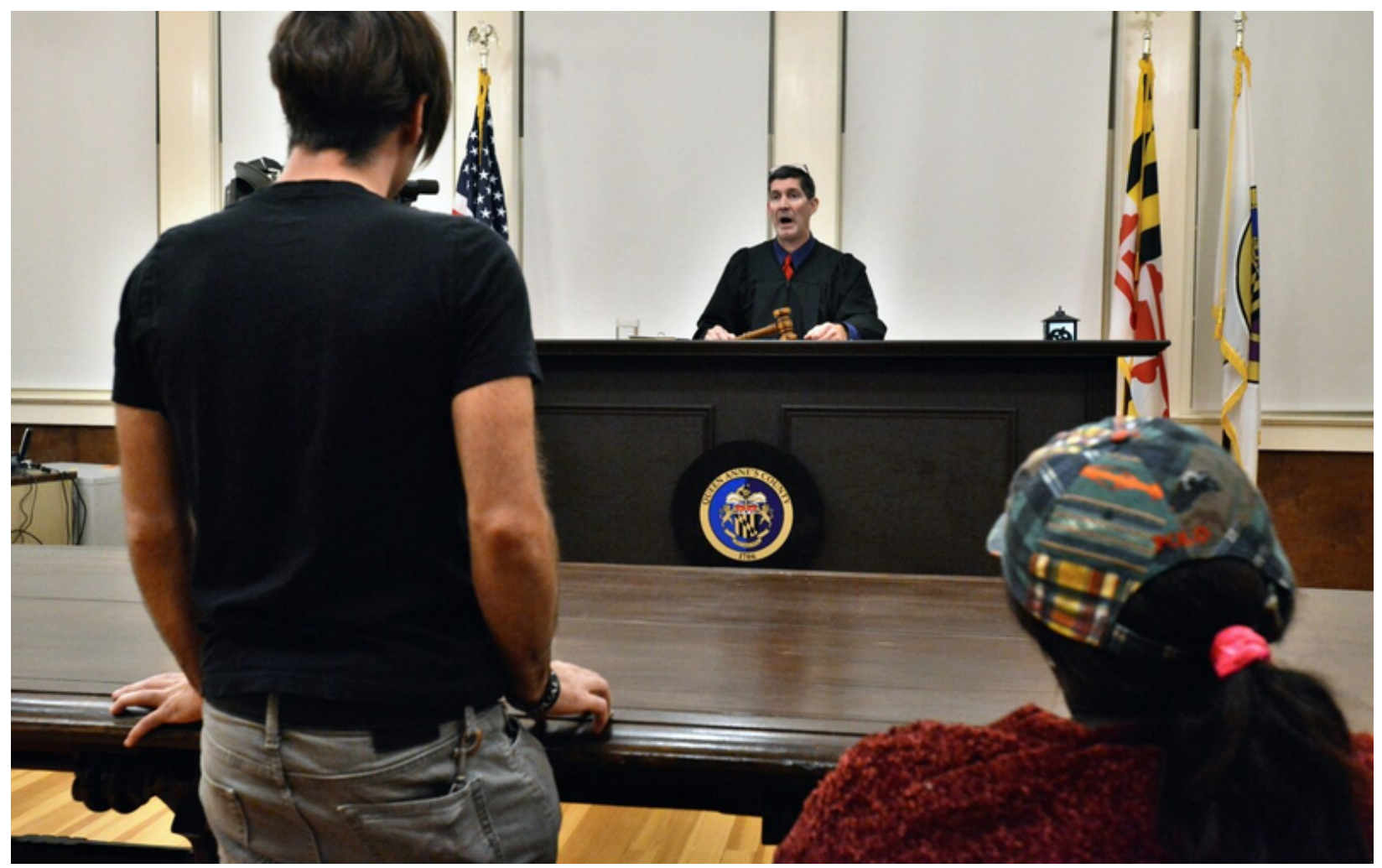

Description: "Cambre Jenkins (right) and another actor (left) play a young woman with a drug dealer boyfriend." Image by Dermot Tatlow and caption by Allen (2019).

The Trap House creates representations of real life. However, the event organizers choose what represents substance use by relying on stereotypes and metaphors (Linnemann et al., 2013), with "each room representing a different scene in the life of a drug abuser" (CNS Maryland, 2019). Media accounts only interview those directly involved with the event, including former opioid substance users, who speak in support of the program. Those who may disagree with this dramatization were not provided a platform.

On social media, reviews of the "Haunted Trap House" are positive and affirm the antisubstance use message. One visitor notes, "I think it really is great opportunity to teach our middle school children the dangers of hard drugs, before they are exposed to situations themselves" (Haunted Trap House, 2019). The incarcerated people used in the event also served as the target of advice, rather than source of information from their own experience, with one visitor explaining that "My favorite part was telling the actual inmate that was in there for 18 months because of DUI that I am almost 5 years (sober). I told him that he will be strong enough to stay sober if he really wanted to. That part really pulled at my heart strings" (Haunted Trap House, 2019). There is no 
coverage of racialized people speaking about the school-to-prison pipeline and legacies continuing from segregated schools. While relevant, accounts of the school-to-prison pipeline by Black students, such as one provided Theron (a Maryland student who participated in research about education), are missing from the event: "sometimes we get looked at different by our White or Caucasian teachers, but we also get looked at by police watching you while you on your way to school thinking you have something on you because you Black and you a male. They stereotype us a lil too much but that's something that's never going to change" (Grace \& Nelson, 2018).

\section{Discussion and conclusion}

The meanings of confinement communicated at these sites rely on stereotypes, tropes and dominant storylines. Events are marketed as educational and entertainment, yet draw little from actual history and real experiences, instead privileging the carnivalesque (Presdee, 2017). These penal imaginaries border on fantasy, reflecting neoliberal ideas pertaining to individualism in both state-run and private enterprises (Moore, 2013). For the for-profit enterprises, these examples demonstrate a tendency to commodify human suffering and punishment. The proliferation of entertainmentoriented forms of dark tourism is a trend. Some of these arrangements and networks involving non-profits and state-run sites also show the overlap between penal system entities and the charity sector (Tomczak \& Buck, 2019; Maguire et al., 2019), although relying on such shaming tropes runs opposite to the mandates of many non-profits in the social services sector that work with people pushed to the margins requiring inclusion.

Mason and Sayner (2019) describe several ways that silence manifests in museum spaces. Silence of a museum can reflect a broader societal silence about some issues. A museum staff member can decide that a conversation or set of ideas does not belong to them or is not their responsibility to address (Ferguson et al., 2019). Silence can be by design. In addition to the stereotypical representations on display at these sites, there are also many silences in these depictions of confinement we examine. Lower Fort Garry portrays RCMP and settlers as saviors, ignoring the ongoing colonial violence targeting Indigenous people including through disproportionate tuberculosis rates and police brutality. Tranquille Sanitorium construes the site as a haunted and frightening location, claiming both to tell true history, while also maintaining as its goal to frighten and attract as much attention as possible for future development. Pennhurst Asylum removed the historical information displays from one of the buildings, and hires "patients" and "medical staff" to act as zombies and monsters. The 
Centreville "Haunted Trap House" parades scenes of criminalization and uses a criminalized person as part of its event offerings, yet is silent on the role of criminalization in the overdose epidemic, the hyper imprisonment of Black and other racialized people, and its location in a former segregated school.

Across the cases, and throughout Canada and the United States, there are not many differences in how illness, ability, colonialism, and confinement are portrayed in penal imaginaries. There is a lack of empathy to suffering, and the deservingness of those confined to respectful action and memory. Such messaging extends to opinions of deservingness of criminalized people present today, including those currently confined, now deinstitutionalized, or who would have been institutionalized if they lived in another time. In these sites, the doxic instinct is to portray "others" as monstrous, unintelligible, and to be avoided, rather than as human beings, neighbours, and loved ones to be afforded compassion and care. The default is to view "others" as deserving of scorn and punishment, especially those living along the intersections of institutionalization, racism, classism, ableism, sexism, and more.

In terms of differences, there appears to be a trend of "franchise-style" fright night venues in the United States, which have yet to appear in Canada. The Pennhurst Asylum marketing employs imagery (e.g., extreme dramatizations, click-bait, gore), which is also found in other commercialised fright night ventures. The commercialization of these penal imaginaries suggests a willingness to profit from denigration and suffering of others. Another difference is there are more sheriff-run events in the United States (e.g., Polk County and Bernalillo County). Police are also involved at the Maryland "Trap House." While police do not actively operate events in Canada, they are occasionally participants, including the RCMP evoked at Lower Fort Garry, Manitoba. Police involvement is relevant, as they provide a sense of authenticity and legitimacy, while also being provided with an opportunity to engage with the public in a "positive" manner.

In contrast to depictions of carceral agents as protectors, the use of health tropes to further denigrate and dangerize imprisoned persons creates layers of ideological meaning that often make it appear as if prisoners are irredeemable monsters requiring confinement. These displays invoke health tropes concerning contagion to intensify fears regarding incarcerated people, suggesting that imprisoned persons are a health threat to the social body, further rationalizing the existence of confinement as a means of addressing social unease and anxieties about safety and security. These shaming and stereotypical representations are damaging, both individually and socially. Yet 
their symbolic punishment and brutalization in staged cultural scenes is meant to be entertaining. The ethics of creating such images and fostering a social distance between the prisoner and the penal spectator (Brown, 2017) does not appear to be of concern for organizers, who should care about the legacies of their activities.

In the context of the COVID-19 pandemic, these findings that reveal how incarcerated people are used as scapegoats upon which social unease and anxieties are projected are all the more significant. While the events we examine in this paper occurred before the pandemic, such fright night events continue feeding into anxieties about risk during the pandemic. Through our abolition activist work on the carceral, we hear firsthand how the pandemic is a tense time where some neighbours surveil and snitch on each other (Bonotti \& Zech, 2021), police are empowered to fine and arrest people for breaking pandemic rules around distancing and hygiene (McClelland, 2020), and institutions of confinement are sites of serious outbreaks (Walby \& Piché, 2020; Chartrand, 2021). We have heard from BIPOC community members that they are especially at risk of COVID-19 infection, with little assistance to mitigate the exposure they face. BIPOC are also confined at a hyper scale both in the United States (Alexander, 2010) and Canada (Maynard, 2017; Chartrand, 2019), bearing the brunt of societal stigma and tropes about risk, health, and deservingness. There is a lack of dignity and safety for people in institutions, where it is impossible to be safe, to practice hygiene (e.g., no hand sanitizer provided), and to isolate (Burki, 2020). Through fright night events, messaging portrays institutionalized people, particularly BIPOC, as underserving of due support and services. Such messaging can create real world impacts, including justifications of who should receive support versus who should be subject to containment in the face of COVID-19. In this context, where the probability of death by imprisonment has only increased (Schwartzapfel et al., 2020), challenging and confronting penal imaginaries has never been more urgent.

\section{Implications}

In terms of a contribution to qualitative criminology, we have added to knowledge of penal spectatorship in the United States and Canada. Locating common themes across multiple sites, we have demonstrated how these sites tend to rely on denigrating visual displays of prisoners that invoke racializing tropes concerning disease and so-called criminality. We have drawn attention to the visual politics of these displays by interpreting the curatorial and performative aspects the initiatives. We have also shown how the idea of penal imaginaries can be usefully applied to scenes of penal spectatorship, penal tourism, and penal heritage. In terms of a contribution to 
quantitative criminology, future research could use different methodological tools to explore such popular penal culture sites. For example, extending our findings to generate testable hypotheses, quantitative criminologists could use surveys to systematically assess the penal ideologies and imaginaries of staff, volunteers, guests, and tourists who work at and visit these sites. It is also important to explore if there is regional and national variation in these views, and how these views may inform penal policy in those jurisdictions.

In terms of a contribution to practice, we suggest that the designers and curators of these displays should heed the lessons of critical curatorial studies (Reilly, 2018). Critical curatorial studies draw attention to the power relations implied in the way museum and heritage displays are assembled and consumed, as well as issues of recognition and representation. It is important to decolonize and deconstruct popular culture and heritage displays using the tools of critical curatorial studies, as well as feminist and critical race curatorial approaches. People who are othered by displays must have space to express how or if their stories should be told at sites. We have noted the silences and absences concerning colonialism in these forums for penal spectatorship. We have likewise examined the racializing tropes concerning disease and "criminality" conveyed. We have drawn attention to the visual politics of these displays by interpreting the representations communicated at these sites. These are forms of display that critical curatorial studies, as well as feminist and critical race curatorial approaches, can address and amend.

We also suggest that anyone assembling museum and heritage displays about incarcerated people and criminalized groups should be more inclusive in their approaches to creating popular culture (Fiander et al., 2016). By not including the voices of imprisoned persons and criminalized groups in the process, these penal spectatorship initiatives and popular penal culture sites are producing more shame, stigma, and exclusion in our world.

\section{References}

Abeysinghe, Sudeepa, and White, Kevin. (2010). The Avian Influenza Pandemic:

Discourses of Risk, Contagion and Preparation in Australia. Health, Risk \& Society, 13/4, 311-326.

Alexander, Michelle. (2010). The New Jim Crow: Mass Incarceration in the Age of Colorblindness. New York: The New Press. 
Allen, Nick. (2019). Residents of opioid-blighted town create 'haunted house' to tell the destructive story of addiction. The Telegraph, 26 October.

https://www.telegraph.co.uk/news/2019/10/26/residents-opioid-blighted-town-createhaunted-house-tell-destructive/.

Andersen, Chris. (2014). Métis: Race, Recognition, and the Struggle for Indigenous Peoplehood. Vancouver: UBC Press.

Appleman, Laura. (2018). Deviancy, Dependency, and Disability: The Forgotten History of Eugenics and Mass Incarceration. Duke Law Journal, 68/3, 417-478.

Armstrong, Sarah. (2018). The Cell and the Corridor: Imprisonment as Waiting, and Waiting as Mobile. Time \& Society, 27/2, 133-154.

Baldini, Bill. (1968). Suffer the Little Children. NBC.

Beitiks, Emily. (2014). The Ghosts of Institutionalization at Pennhurst's Haunted Asylum. Hastings Center Report, 42/1.

Block, Tina. (2018). The Tranquille Oral History Project: Reflections on a CommunityEngaged Research Initiative in Kamloops, British Columbia. In No Straight Lines: Local Leadership and the Path from Government to Governance in Small Cities. Kadin, T. (ed). (pp. 205-226). Calgary: University of Calgary Press.

Bonotti, Matteo and Zech, Steven T. (2021). Civility as Politeness During COVID-19. Nature Public Health Emergency Collection, 3, 65-120.

Brown, Michelle. (2017). Penal Optics and the Struggle for the Right to Look: Visuality and Prison Tourism in the Carceral Era. In The Palgrave Handbook of Prison Tourism. Wilson, J. Z., Hodgkinson, S., Piché, J. and Walby, K. (eds). (pp. 153-167). London: Palgrave Macmillan.

Brown, Michelle. (2009). The Culture of Punishment: Prison, Society, and Spectacle. New York: NYU Press.

Brown, Michelle, and Carrabine, Eamonn. (2019). The Critical Foundations of Visual Criminology: The State, Crisis, and the Sensory. Critical Criminology, 27/1, 191-205.

Burke, Stacie. (2018). Building Resistance. McGill-Queen’s University Press.

Burki, Talha. (2020). Prisons are "in no way equipped" to Deal with COVID-19. Lancet, 295, 1411-1412. 
Calathes, William. (2017). Racial Capitalism and Punishment Philosophy and Practices: What Really Stands in the Way of Prison Abolition. Contemporary Justice Review, 20/4, 442-455.

Canadian Press. (2018). Woodlands survivors begin receiving compensation from B.C. government. Vancouver Sun, 8 October.

https://www.theglobeandmail.com/canada/article-woodlands-survivors-begin-receivingcompensation-from-bc-government-2/.

Carlen, Pat. (2008). Imaginary Penalities and Risk-Crazed Governance. In Imaginary Penalties. Carlen, P. (ed). (pp. 1-21). Cullompton: Willan.

Carrabine, Eamonn. (2016). Picture This: Criminology, Image and Narrative. Crime Media Culture, 12/2, 253-270.

Chartrand, Vicki. (2021). Abolition in the land known as Canada in the wake of COVID19. Current Issues in Criminal Justice, Online First.

Chartrand, Vicki. (2019). Unsettled Times: Indigenous Incarceration and the Links between Colonialism and the Penitentiary in Canada. Canadian Journal of Criminology and Criminal Justice, 61/3, 67-89.

Chimera Theatre. (2018). Are you afraid of the dark ... Facebook, 25 September. https://www.facebook.com/chimeratheatre/photos/2354172741265608.

CNS Maryland. (2019). Take a walk through Centreville's Opioid Haunted House. CNS Maryland, 19 November. https://cnsmaryland.org/2019/11/19/take-a-walk-throughcentrevilles-opioid-haunted-house/.

Corcoran, Mary. (2011). Dilemmas of Institutionalization in the Penal Voluntary Sector. Critical Social Policy, 31/1, 30-52.

Coutts, Robert. (2016). Heritage and the Landscape of Memory: Commemorating the Fur Trade in Manitoba. Manitoba History, 81, 7-15.

Daschuk, James. (2013). Clearing the Plains: Disease, Politics of Starvation, and the Loss of Aboriginal Life. Regina: University of Regina Press.

Davis, Angela Y. and Mendieta, Eduardo. (2005). Abolition Democracy: Beyond Empire, Prisons, and Torture. New York: Seven Stories Press. 
De Giorgi, Alessandro. (2010). State Power, Democratic Process, and Human Rights: Countering the Penal Imaginary. Theoretical Criminology, 14/3, 369-379.

Devine, Jennifer. (2016). Contesting Global Heritage in the Chicle Worker's Museum. Latin American Research Review, 51/3, 101-122.

Donald, Dwayne. (2009). Forts, Curriculum, and Indigenous Metissage: Imagining Decolonization of Aboriginal-Canadian Relations in Educational Contexts. First Nations Perspectives, 2/1, 1-24.

Downey, Dennis, and Conroy, James. (2020). Pennhurst and the Struggle for Disability Rights. Keystone Books.

Downey, Dennis. (2017). “Detect early; Protect always”: Philadelphia Physicians and the Gospel of Eugenics. Pennsylvania Legacies, 17/2, 12-19

Drees, Laurie. (2013). Healing Histories: Stories from Canada's Indian Hospitals. Edmonton: University of Alberta Press.

Dunham, Jackie. (2017). Resistance 150: Why Canada's birthday celebrations aren't for everyone. CTV News, 27 June. https://www.ctvnews.ca/canada/resistance-150-whycanada-s-birthday-celebrations-aren-t-for-everyone-1.3478004.

Dvorak, Petula. (2019). This town turned its opioid nightmare into a haunted house. And it's terrifying. The Washington Post, 21 October.

https://www.washingtonpost.com/local/this-town-turned-its-opioid-nightmare-into-ahaunted-house-and-its-terrifying/2019/10/21/96aead02-f421-11e9-8cf04cc99f74d127_story.html.

Edensor, Tim. (2001). Performing Tourism, Staging Tourism: (Re)producing Tourist Space and Practice. Tourist Studies, 1/1, 59-81.

Elo, Satu and Helvi Kyngas. (2008). The Qualitative Content Analysis Process. Journal of Advanced Nursing, 62/1, 107-115.

Farm Fresh. (2019). Escape from Padova.

https://tranquillefarmfresh.com/events/escape-from-padova/.

Ferguson, Matthew, Piché, Justin and Walby, Kevin. (2019). '...that's not a conversation that belongs to the museum': The (In)visibility of Surveillance History in Police Museums in Ontario, Canada. In Making Surveillance States: Transnational Histories. 
Heynen, Robert and van der Meulen, Emily (eds). (pp. 282-305). Toronto: University of Toronto Press.

Fiander, Sarah, Chen, Ashley, Piché, Justin and Walby, Kevin. (2016). Critical Punishment Memorialization in Canada. Critical Criminology, 24/1, 1-18.

Forsdick, Charles. (2019). Bande dessinée and the Penal Imaginary: Graphic Constructions of the Carceral Archipelago. European Comic Art, 12/2, 1-16.

Gallant, Victor, Duvvuri, Venkata, and McGuire, Manson. (2015). Tuberculosis in Canada - Summary 2015. Canada Communicable Disease Report, 43(3-4), 77-82.

Gilbert, Robb and revised by Fedorak, Jamie. (2018). Tranquille Sanatorium Collection. Kamloops Museum and Archives.

https://www.kamloops.ca/sites/default/files/docs/parksrecreation/tranquillesanatorium.pdf.

Globe and Mail. (2003). B.C. government apologizes to abuse victims. Globe and Mail, 30 May. https:/www.theglobeandmail.com/news/national/bc-government-apologizes-toabuse-victims/article1161750/.

Grace, Jennifer and Nelson, Steven. (2018). "Tryin' to Survive”: Black Male Students' Understandings of the Role of Race and Racism in the School-to-Prison Pipeline. Leadership and Policy in Schools, 18/4, 664-280.

Hall, Stuart. (1997). The Spectacle of the 'Other'. In Representation: Cultural Representations and Signifying Practices. Hall, Stuart (ed). (pp. 223-290). London: Sage.

Huang, Shu-Mei and Lee, Hyun-Kyung. (2020). Heritage, Memory, and Punishment: Remembering Colonial Prisons in East Asia. London: Routledge.

Haunted Crack House. (2019). What the project is about. https://www.hauntedcrackhouse.com/.

Haunted Trap House. (2019). Haunted Trap House. Facebook, 25 October. https://www.facebook.com/events/381290852535136/?active_tab=discussion. Higgins, Ethan, and Swartz, Kristin. (2018). The Knowing of Monstrosities: Necropower, Spectacular Punishment and Denial. Critical Criminology, 26/1, 91-106. 
Hunter, Morgan. (2018). Padova Asylum gets spooky just in time for Halloween. The Omega, 26 September. http://truomega.ca/2018/09/26/padova-asylum-gets-spooky-justin-time-for-halloween/.

Jaime, Kristian. (2019). Haunted Trap House ready to scare. The Bay Times and Record Observer, 24 October.

https://www.myeasternshoremd.com/qa/community/news/haunted-trap-house-ready-toscare/article_b5dd8046-e129-5f7b-a505-1c413fb257f6.html.

Johnson, Roland and Williams, Karl. (1994). Lost In A Desert World: An Autobiography. https://www.disabilitymuseum.org/dhm/lib/detail.html?id=1681\&page=all\#1.

Kamarulzaman, Adeeba, et al. (2016). Prevention of Transmission of HIV, Hepatitis B Virus, Hepatitis C Virus, and Tuberculosis in Prisoners. The Lancet, 388(10049), 11151126.

Kulesza, Magdalena, Matsuda, Mauri, and Ramiraz, Jason. (2016). Towards Greater Understanding of Addiction Stigma: Intersectionality with Race/Ethnicity and Gender. Drug and Alcohol Dependence, 169, 85-91.

Kennard African American Cultural Heritage Centre (KAACHC). (2018). Kennard High School History. https://kennardheritage.com/kennard-high-school/.

Kinzelbach, Annemarie. (2006). Infection, Contagion, and Public Health in Late Medieval and Early Modern German Imperial Towns. Journal of History of Medicine and Allied Sciences, 61/3, 369-389.

Kuperavage, Jessica. (2017). Visualizing Risk: Images, Risk and Fear in a Health Campaign. Journal of Medical Humanities, 38, 115-132.

Lafontaine, Constance, Sawchu, Kim, and DeJong, Scott. (2020). Social Justice Games: Building an Escape Room on Elder Abuse through Participatory Action Research. The Computer Games Journal, 9, 189-205.

Linnemann, Travis, Hanson, Laura, and Williams, Susan. (2013). 'With Scenes of Blood and Pain': Crime Control and the Punitive Imagination of The Meth Project. British Journal of Criminology, 53/4, 605-623.

Lucken, Karol. (2013). You Say Regulation, I Say Punishment: The Semantics and Attributes of Punitive Activity. Critical Criminology, 21/2, 193-210. 
Lux, Maureen. (2016). Separate Beds: A History of Indian Hospitals in Canada, 1920s1980s. Toronto: University of Toronto Press.

Lux, Maureen. (2010). Care for the 'Racially Careless': Indian Hospitals in the Canadian West, 1920-1950s. The Canadian Historical Review, 91/3, 407-434.

Maguire, Mike, Williams, Katherine, and Corcoran, Mary. (2019). 'Penal Drift' and the Voluntary Sector. The Howard Journal of Crime and Justice, 58/3, 430-449.

Maryland Opioid Operational Command Centre. (2020). Quarterly Report January 1, 2020 - March 31.

https://bha.health.maryland.gov/Documents/OOCC\%20CY20\%20Q1\%20OD\%20Death\% 20data\%20June2020.pdf.

Mason, Rhiannon, and Sayner, Joanne. (2019). Bringing Museal Silence into Focus: Eight ways of Thinking about Silence in Museums. International Journal of Heritage Studies, 25/1, 5-20.

Maynard, Robyn. (2017). Policing Black Lives: State Violence in Canada From Slavery to the Present. Halifax: Fernwood.

Mayring, Phillip. (2004). Qualitative Content Analysis. In A Companion to Qualitative Research. Flick, U., von Kardoff, E. and Steinke, I. (eds). (pp. 266-270). London: Sage.

McClelland, Alexander. (2020). We Can't Police Our Way Out of a Pandemic. In Sick of the System: Why the COVID-19 Recovery Needs to be Revolutionary. Between The Lines Editorial Collective (eds). (pp.60-64). Toronto: Between The Lines.

McNeill, Fergus (2019). Penal and Welfare Conditionality: Discipline or Degradation? Social Policy Administration, 54/2, 295-310.

Moore, Kerry. (2013). 'Asylum Shopping' in the Neoliberal Social Imaginary. Media, Culture \& Society, 35/3, 348-365.

Morris, Patricia, and Arford, Tammi. (2019). "Sweat a little water, sweat a little blood": A Spectacle of Convict Labor at an American Amusement Park. Crime, Media, Culture, $15 / 3,423-446$.

National Inquiry into Missing and Murdered Indigenous Women and Girls. (2019). Reclaiming Power and Place. https://www.mmiwg-ffada.ca/final-report/. 
Norton, Wayne and Miller, Naomi. (2000). A Whole Little City by Itself: Tranquille \& Tuberculosis. BC Historical News, 33/3, 31.

Nunn, Kenneth. (2002). Race, Crime and the Pool of Surplus Criminality: Or Why the War on Drugs was War on Blacks. Journal of Gender, Race and Justice, 6/2, 381-446.

Ott, Brian, Aoki, Eric, and Dickinson, Greg. (2011). Ways of (not) Seeing Guns: Presence and Absence at the Cody Firearms Museum. Communication and Critical/Cultural Studies, 8/3, 215-239.

Palmater, Pamela. (2016). Shining Light on the Dark Places: Addressing Police Racism and Sexualized Violence against Indigenous Women and Girls in the National Inquiry. Canadian Journal of Women and the Law, 28/2, 253-284.

Parks Canada. (2019). Lower Fort Garry. https://www.pc.gc.ca/en/lhnnhs/mb/fortgarry/info.

Patel, Smit, Paulsen, Catherine, and Hefferman, Courtenay. (2017). Tuberculosis Transmission in the Indigenous Peoples of the Canadian Prairies. PLOS One, https://doi.org/10.1371/journal.pone.0188189.

Patraka, Vivian. (2001). Spectacular Suffering: Performing Presence, Absence, and Witness at US Holocaust Museums. In Memory and Representation: Constructed Truths and Competing Realities. Eber, E. and Neal, A. (eds). (pp. 139-166). Bowling Green: Bowling Green State University Popular Press.

Patterson, M., Flinn, Sydney, and Barker, K. (2018). Addressing Tuberculosis among Inuit in Canada. Canada Communicable Disease Report, 44(3-4), 82-85.

Pennhurst Memorial \& Preservation Alliance. (2015). Pennhurst Timeline. http://www.preservepennhurst.org/default.aspx?pg $=93$.

Pennhurst Asylum. (n.d.a). Attractions. https://pennhurstasylum.com/attractions/.

Pennhurst Asylum (n.d.b) Pennhurst Asylum. https://pennhurstasylum.com/.

Pew Research Center. (2019). Fact Tank: The Gap Between the Number of Blacks and Whites in Prison is Shrinking. Washington DC: Pew Research Center. https://www.pewresearch.org/facttank/2019/04/30/shrinking-gap-between-number-ofblacksand-whites-in-prison/. 
Presdee, Mike, and Carver, Gavin. (2017). From Carnival to the Carnival of Crime. In Cultural Criminology: Theories of Crime. Ferrell, J. and Hayward, K. (eds). (pp. 31-56). London: Routledge.

Potestio, Michael. (2018). Find your escape at Padova. Kamloops This Week, 31 August. https://www.kamloopsthisweek.com/entertainment/find-your-escape-at-padovacity-1.23419027.

Purvey, Diane. (2018). "Thrown Out into the Community": The Closure of Tranquille. In Small Cities, Big Issues: Reconceiving Community in a Neoliberal Era. Walmsley, C. and Kading, T. (eds). (pp. 125-146). Edmonton: Athabasca University Press.

Razack, Sherene. (2015). Dying from Improvement: Inquests and Inquiries into Indigenous Deaths in Custody. Toronto: University of Toronto Press.

Razack, Sherene. (2014). "It Happened More Than Once": Freezing Deaths in Saskatchewan. Canadian Journal of Women and the Law, 26/1, 51-80.

Reardon, Sean and Owens, Ann. (2014). 60 Years After Brown: Trends and Consequences of School Segregation. Annual Review of Sociology, 40, 199-218.

Reilly, Maura. 2018. Curatorial Activism: Towards an Ethics of Curating. New York: Thames and Hudson.

Rousseau, Cella. (2015). Lower Fort Scary. Uniter, 29 October.

http://uniter.ca/view/lower-fort-scary.

Sargent, Carolyn, and Larchanché, Stephanie. (2014). Disease, Risk, and Contagion: French Colonial and Postcolonial Constructions of "African" Bodies. Journal of Bioethical Inquiry, 11, 455-466.

Sealey-Ruiz, Yolanda. (2011). Dismantling the School-to-Prison Pipeline Through Racial Literacy Development in Teacher Education. Journal of Curriculum and Pedagogy, 8/2.

Shaw, Rob. (2018). B.C. government to compensate pre-1974 Woodlands residents. Vancouver Sun, 1 April. https://vancouversun.com/news/local-news/5-am-web-embargob-c-government-provides-compensation-to-former-woodlands-residents

Shepert, Elana. (2019). This creepy abandoned sanatorium in B.C. will give you nightmares. Vancouver is Awesome, 17 April. 
https://www.vancouverisawesome.com/travel/tranquille-sanatorium-abandoned-bc1943289.

Spikol, Liz. (2017). Is this how people see me? What happened when I visited Pennhurst's Haunted Asylum. The Philadelphia Inquirer, 19 October.

https://www.inquirer.com/philly/opinion/commentary/pennhurst-asylum-hospitalhaunted-house-mental-health-20171019.html.

Solomon, Arthur. (1990). If There is No Justice There is No Peace. Journal of Prisoners on Prisons, 2/2, 29-38.

Substance Abuse and Mental Health Services Administration (SAMHSA). (2020). The Opioid Crisis and the Black/African American Population: An Urgent Issue. US Department of Health and Human Services. https://store.samhsa.gov/sites/default/files/SAMHSA_Digital_Download/PEP20-05-02001_508\%20Final.pdf.

Schwartzapfel, Beth, Park, Katie, and Demillo, Andrew. (2020). 1 in 5 Prisoners in the U.S. Has Had COVID-19, The Marshall Project, 18 December. https://www.themarshallproject.org/2020/12/18/1-in-5-prisoners-in-the-u-s-has-hadcovid-19.

Stuit, Hanneke. (2020). Carceral Projections: The Lure of the Cell and the Heterotopia of Play in Prison Escape. In The Prison Cell. Turner, J. and Knight, V. (eds). (pp. 305325). London: Palgrave.

Taiaiake Alfred, Gerald, and Corntassel, Jeff. (2005). Being Indigenous: Resurgences against Contemporary Capitalism. Government and Opposition, 40/4, 597-614.

Taxy, Sam, Samuels, Julie, and Adams, William. (2015). Drug Offenders in Federal Prison: Estimates of Characteristics Based on Linked Data. Washington DC: U.S. Department of Justice, Office of Justice Programs, Bureau of Justice Statistics. https://www.bjs.gov/content/pub/pdf/dofp12.pdf.

Tomczak, Phillipa, and Buck, Gillian. (2019). The Criminal Justice Voluntary Sector: Concepts and an Agenda for an Emerging Field. Howard Journal of Crime and Justice, 58/3, 276-297.

Tourism Winnipeg. (2015). Halloween in Winnipeg is happening all month long. https://www.tourismwinnipeg.com/things-to-do/only-in-thepeg/read,post/148/halloween-in-winnipeg-is-happening-all-month-long. 
Travel Manitoba. (2015). Halloween in Manitoba.

https://www.travelmanitoba.com/blog/post/halloween-in-manitoba/.

Trip Advisor. (2011). Lower Fort Garry. https://www.tripadvisor.ca/Attraction_Reviewg3317237-d156228-Reviews-Lower_Fort_Garry_National_Historic_Site-

St_Andrews_Manitoba.html.

Tripadvisor (2016, 2017, 2018, 2019). PennHurst Asylum.

https://www.tripadvisor.ca/Attraction_Review-g53733-d5226405-Reviews-or5-

Pennhurst_Asylum-Spring_City_Pennsylvania.html\#REVIEWS.

Trip Advisor. (2018). Tranquille Farm. https://www.tripadvisor.ca/ShowUserReviewsg154932-d3576295-r444904608-Tranquille_Farm_Fresh-

Kamloops_British_Columbia.html.

Trudeau, Megan. (2018). This abandoned sanitarium in B.C. has been turned into a terrifying escape room. Kelowna Now, 20 October.

https://www.kelownanow.com/watercooler/news/news/Entertainment/This_abandoned_s anitarium_in_B_C_has_been_turned_into_a_terrifying_escape_room/.

Voorhis, Ernest. (1930). Historic Forts and Trading Posts of the French regime and of the English Fur Trading Companies. Ottawa: Department of the Interior.

Walby, Kevin and Piché, Justin. (2020). Voices from the Inside, Voices from Beyond: Reflections on the (Prison) Pandemic. Journal of Prisoners on Prison, 29(1\&2), 1-6.

Walby, Kevin and Piché, Justin. (2015). Making Meaning out of Punishment:

Penitentiary, Prison, Jail, and Lock-up Museums in Canada. Canadian Journal of Criminology and Criminal Justice, 57/4, 475-502.

Walters, P. (2010). Haunted House at Asylum Doesn't Thrill All. Los Angeles Times, 26 September 2010.

Watkins-Hayes, Celeste and Kovalsky, Elyse. (2016). The Discourse of Deservingness. In The Oxford Handbook of the Social Science of Poverty. Brady, D. and Burton, L. (eds). (pp. 193-220). Oxford: Oxford University Press.

Webmoor, Timothy. (2008). From Silicon Valley to The Valley of Teotihuacan: The "Yahoo's" of New Media and Digital Heritage. Visual Anthropology Review, 24/2, 183200 
Welch, Michael. (2013). Penal Tourism and a Tale of Four Cities: Reflecting on the Museum Effect in London, Sydney, Melbourne, and Buenos Aires. Criminology \& Criminal Justice, 13/5, 479-505.

Welch, Michael. (2015). Escape to Prison: Penal Tourism and the Pull of Punishment. Los Angeles: University.

Wilson, Jacqueline Z., Hodgkinson, Sarah, Piché, Justin and Walby, Kevin. (2017). The Handbook of Prison Tourism, London: Palgrave.

\section{Contributors}

Linda Mussell is graduating with her PhD in Political Studies from Queen's University (June 2021). She is an incoming Postdoctoral Fellow at University of Ottawa (September 2021). Her research uses critical policy analysis to interrogate carceral systems, particularly confinement in jails and prisons. Through her work she supports transformative justice and disrupting the harmful direct and intergenerational impacts of carceral policy.

Kevin Walby, $\mathrm{PhD}$, is Associate Professor in the Department of Criminal Justice at the University of Winnipeg. He is co-author with R. Lippert of Municipal Corporate Security in International Context (2015, Routledge) and A Criminology of Policing and Security Frontiers (2019, Bristol). He is co-editor of Brokering Access: Power, Politics, and Freedom of Information Process in Canada with M. Larsen (2012, UBC Press). He has co-edited with R. Lippert Policing Cities: Urban Securitization and Regulation in the 21st Century (2013, Routledge) and Corporate Security in the 21st Century: Theory and Practice in International Perspective (2014, Palgrave). He is co-editor of Access to Information and Social Justice with J. Brownlee (2015, ARP Books) and The Handbook of Prison Tourism with J. Wilson, S. Hodgkinson, and J. Piché (2017, Palgrave-Macmillan). He is co-editor of Corporatizing Canada: Making Business Out of Public Service with J. Brownlee and C. Hurl (2018, Between the Lines Press). He is also co-editor of the Journal of Prisoners on Prisons.

Justin Piché, PhD, is Associate Professor in the Department of Criminology and Director of the Carceral Studies Research Collective at the University of Ottawa. He is also Co-editor of the Journal of Prisoners on Prisons and Co-founder of the Criminalization and Punishment Education Project. He was awarded the Aurora Prize in 2012 from the Social Sciences and Humanities Research Council of Canada, as well as the 2016 Young Researcher of the Year Award and 2020 Activities in the Media or Community Award from the Faculty of Social Sciences at the University of Ottawa. 


\section{Acknowledgements}

This research was funded by a Social Science and Humanities Research Council of Canada Insight Grant (435-2017-0100).

\section{Reviews}

